\title{
NUTRITIONAL STATUS, VITAMIN D AND NASAL COLONIZATION IN SPINAL SURGERY
}

\author{
ESTADO NUTRICIONAL, VITAMINA D E COLONIZAÇÃO NASAL NA CIRURGIA DA COLUNA VERTEBRAL
}

\author{
ESTADO NUTRICIONAL, VITAMINA D Y LA COLONIZACIÓN NASAL EN \\ LA CIRUGÍA DE LA COLUMNA VERTEBRAL
}

\author{
Diego Benone dos Santos ${ }^{1}$, Raphael de Rezende Pratali1, Samuel Machado Martins ${ }^{1}$, Carla Balkanyi Hoffman", \\ Carlos Eduardo Gonçales Barsotti ${ }^{1}$, Francisco Prado Eugenio dos Santos ${ }^{1}$, Carlos Eduardo Algaves Soares de Oliveira ${ }^{1}$
}

1. Orthopedics and Traumatology Service of the Hospital do Servidor Público Estadual de São Paulo.

\begin{abstract}
Objective: Evaluate the nutritional status, vitamin D, the serum albumin, and the nasal colonization by bacteria in a Brazilian population sample that included specifically patients undergoing spine surgery Methods: The serum albumin and vitamin D tests were performed on blood samples; nasal microbiological research was performed by swab and demographic information was collected. We studied the correlation between the tests and gender and age groups of patients. Results: Seventy-five patients were included. Of this total, 74 patients underwent testing of albumin levels, 64 of vitamin $D$ and 41 underwent nasal swab. The mean of serum albumin was $3.76 \mathrm{~g} /$ $\mathrm{dl}(\mathrm{SD}=0.53 \mathrm{~g} / \mathrm{dl}) ; 70.3 \%$ of subjects were considered normal and $29.7 \%$ showed hypoalbuminemia. Regarding vitamin $\mathrm{D}$, the mean was $16.64 \mathrm{ng} / \mathrm{ml}$ (SD: $7.43 \mathrm{ng} / \mathrm{ml}$ ); $64.1 \%$ of patients were considered deficient, $32.8 \%$ insufficient, and $3.1 \%$ were considered normal. There was significant difference between albumin and age $(p=0.007)$, being that the greater the age, the lower the albumin. Hypoalbuminemia was significantly more frequent over 60 years $(p<0.001)$. There was no correlation between vitamin $D$ or nasal swab and age $(p=0.603$ and 0.725 , respectively). The correlation between the tests and gender showed no significant difference in any of the parameters. Conclusion: The serum albumin and vitamin D levels and results of nasal swab were presented for a Brazilian sample of patients undergoing spine surgery. It was found correlation between hypoalbuminemia (inferring malnutrition) and age group of patients. Almost all the patients had some degree of vitamin D deficiency, with no correlation with age.
\end{abstract}

Keywords: Spine/surgery, Serum albumin; Vitamin D, Staphylococcus aureus.

\section{RESUMO}

Objetivos: Avaliar o estado nutricional, a vitamina D, a albumina sérica e a colonização nasal por bactérias em uma amostra populacional brasileira que inclui especificamente indivíduos submetidos a cirurgia de coluna vertebral. Métodos: A albumina sérica e a vitamina $D$ foram avaliadas em amostras de sangue; a pesquisa microbiológica nasal foi realizada por swab e as informações demográficas foram coletadas. Estudou-se a correlação entre os exames e sexo e faixas etárias dos pacientes. Resultados: Foram incluídos 75 pacientes. Desse total, 74 pacientes fizeram dosagem de albumina sérica, 64 de vitamina D e 41 foram submetidos a coleta com swab nasal. A média da albumina foi de 3,76 g/dl (DP: 0,53 g/dl), sendo que 70,3\% dos indivíduos foram considerados normais e 29,7\% apresentaram hipoalbuminemia. Quanto à vitamina D, a média foi de 16,64 ng/ml (DP: 7,43 ng/ml); 64,1\% dos pacientes foram considerados deficientes, 32,8\%, insuficientes e 3,1\% foram considerados normais. Houve diferença significante entre albumina e idade $(p=0,007)$, sendo que quanto maior a faixa etária, menor o valor da albumina. A hipoalbuminemia foi significantemente mais frequente acima dos 60 anos ( $p<0,001)$. Não houve correlação entre vitamina $D$ ou swab nasal e idade ( $p=0,603$ e 0,725, respectivamente). A correlação entre os exames e o sexo não mostrou qualquer diferença significante em nenhum dos parâmetros. Conclusão: Foram apresentados os valores de albumina, da vitamina $D$ e o resultado de swab nasal em uma amostra populacional brasileira de pacientes submetidos a cirurgia de coluna vertebral. Houve correlação entre hipoalbuminemia, inferindo-se desnutrição, e faixa etária dos pacientes. Quase todos os pacientes apresentaram algum grau de hipovitaminose $D$, sem correlação com a faixa etária.

Descritores: Coluna vertebral/cirurgia; Albumina sérica; Vitamina D, Staphylococcus aureus.

\section{RESUMEN}

Objetivo: Evaluar el estado nutricional, la vitamina D y la colonización nasal por las bacterias de una muestra de población brasileña que incluyó individuos sometidos a cirugía de la columna vertebral. Métodos: En una muestra de sangre se dosifico la albúmina sérica y la vitamina D; la investigación microbiológica nasal se realizó mediante hisopo (swab) y la información demográfica fue recolectada. Se estudió la correlación entre las pruebas e sexo y grupos de edad de los pacientes. Resultados: Se incluyeron 75 pacientes. De ellos, 74 hicieron la prueba de albúmina sérica, 64 la prueba de vitamina $D$ y de 41 pacientes se hicieron muestras nasales con hisopo. La media de la albúmina fue 3,76 g/dl $(D E=0,53 \mathrm{~g} / \mathrm{dl})$, y $70,3 \%$ de los sujetos eran normales, y un $29,7 \%$ presentaron hipoalbuminemia. En cuanto a la vitamina $D$, el promedio fue de 16,64 ng/ml (DE: 7,43 ng/ml); 64,1\% de los pacientes fueron considerados deficientes, 32,8\% insuficientes y 3,1\% fueron considerados normales. Hubo una diferencia significativa entre la albúmina y la edad ( $p=0,007)$, y cuanto mayor es la edad, menor es el valor de la albúmina. La hipoalbuminemia fue significativamente más frecuente en individuos mayores de 60 años ( $p<0,001)$. No hubo correlación entre la vitamina $D$ o el hisopo nasal y la edad ( $p=0,603$ y 0,725, respectivamente). La correlación entre las pruebas y el sexo no mostró diferencia significativa en ninguno de los parámetros. Conclusiones: Se presentaron los valores de la albúmina, la vitamina $D$ y los resultados de hisopo

Study conducted in the Hospital do Servidor Publico Estadual (HSPE), São Paulo, SP, Brazil,

Correspondence: Raphael de Rezende Pratali Rua Borges Lagoa, 1755, Sala 180, Vila Clementino, São Paulo, SP, Brazil. 04038-034. pratalir@gmail.com 
nasal en una muestra de población brasileña de pacientes sometidos a cirugía de la columna vertebral. Hubo una correlación entre hipoalbuminemia, infiriéndose la desnutrición, y el grupo de edad de los pacientes. Casi todos los pacientes tenían algún grado de deficiencia de vitamina $D$, sin correlación con la edad.

Descriptores: Columna vertebral/cirugía; Albúmina sérica; Vitamina D; Staphylococcus aureus.

\section{INTRODUCTION}

Several systemic factors can affect the rate of complications following spine surgery, possibly compromising the clinical outcome. The nutritional state of the patient stands out among these factors, having been shown to have a negative impact on the rate of healing, to increase the rate of infection, and to affect the consolidation of the arthrodesis. ${ }^{1,2}$ However, malnutrition is frequently not identified during preoperative preparation of individuals who will undergo spine surgery. One of the main indicators of malnutrition is serum albumin lower than $3.5 \mathrm{~g} / \mathrm{dL}{ }^{3,4}$ Serum albumin is the most abundant plasmatic protein and hypoalbuminemia affects the vascular diffusion of nutrients with repercussions for the immune system and for the maintenance of homeostasis in the organism. ${ }^{4}$

Another nutrient of more recently recognized importance is vitamin D, which actually is a liposoluble steroidal hormone with a fundamental function in mineral homeostasis and bone metabolism. ${ }^{5,6}$ Changes in the levels of serum vitamin $D$ can be caused by a deficient diet, but also by intestinal absorption disorders and even by extrinsic factors like lack of sun exposure. Vitamin D deficiency can change the osteoclast-osteoblast relationship with a consequent predisposition for osteoporosis and fractures, in addition to the risk of inhibiting the consolidation of arthrodesis following surgery. ${ }^{5-7}$ Recently, Stoker et al. ${ }^{6}$ studied the prevalence of vitamin $D$ deficiency in patients who underwent spine surgery in the same service in the US, reporting a rate of insufficiency in $57 \%$ and a rate of deficiency in $27 \%$ of the individuals.

Besides the nutritional condition of patients who have undergone spine surgery, another factor that can predispose them to complications is nasal colonization by bacteria, especially Staphylococcus aureus. Various studies have shown that the risk of infection in carriers of this organism is between three and six times higher than in non-carriers. ${ }^{8-11}$ A recent study showed that $18.4 \%$ of hospitalized patients tested positive for $S$. aureus. ${ }^{11}$ The study also showed that identification and decolonization significantly reduced the rate of general and postoperative infections when compared to the individuals treated with the placebo.

However, the information regarding the occurrence of malnutrition, identified by hypoalbuminemia, vitamin $D$ deficiency, and nasal colonization by bacteria comes from studies of other populations, as there was a lack of information in our study. The objective of this study was to evaluate and describe the epidemiological profile of a Brazilian population consisting of individuals who underwent spinal surgery under these nutritional conditions and with bacterial colonization.

\section{METHODS}

The study was a prospective observational epidemiological analysis involving patients who underwent spine surgery procedures in the same service between February and November of 2014. The study was approved by the Institutional Review Board (CAAE: 39410114100005463).

All patients who underwent spine surgery and who, following orientation about the study objectives, agreed to and signed the informed consent form, including minors whose legal guardians agreed to and signed it, were included in the study. In the study, were included patients with different kind of surgical procedures and different pathologies diagnoses, including deformity, cervical and lumbar degenerative disease, trauma and tumors. Only patients who did not agree to sign the consent form or those with problems with their laboratory exam results were excluded.

The night before the surgical procedure, a blood sample was taken to measure the levels of serum albumin and vitamin $D$ and the patient underwent a microbiological nasal swab. Patient demographic information was obtained including age, gender, weight, height, race, smoking status, alcohol consumption, and hospitalization time. Comorbidity analysis was conducted via an anesthesiological evaluation, according to the scale proposed by the American Society of Anesthesiologists (ASA).

The parameters obtained were considered according to the following scheme: normal serum albumin concentration is from 3.5 to $5.5 \mathrm{~g} / \mathrm{dL},{ }^{4}$ values less than $3.5 \mathrm{~g} / \mathrm{dL}$ being considered hypoalbuminemia. The serum concentration of vitamin $\mathrm{D}$ is evaluated by 25 -hydroxyvitamin $\mathrm{D}\left(25(\mathrm{OH}),{ }^{5}\right.$ with values less than $30 \mathrm{ng} / \mathrm{mL}$ considered to be insufficiency and values less than $20 \mathrm{ng} / \mathrm{mL}$ considered as deficiency. ${ }^{5,12}$ An identification of bacterial colonization was made via the microbiological culture of material collected by nasal swab, in search primarily of methicillin-resistant Staphylococcus aureus (ORSA).

A comparison of the albumin and vitamin $D$ values and of the positivity of the nasal swab was conducted between the genders and the different age groups (Group 1 - younger than 18 years of age; Group 2 - from 18 to 39; Group 3 - from 40 to 59; and Group $4-60$ years of age or older). The ANOVA technique was used for the statistical analysis of the age groups and the Student's t-test was used for the genders. The tests were performed with a level of significance of $5 \%$.

\section{RESULTS}

Seventy-five patients were included in the study, 47 of them women (62.7\%) and 28 men (37.3\%). They were divided into age groups: 7 patients $(9.3 \%)$ were younger than 18 years old, five $(6.7 \%)$ were from 18 and 39 years, 29 (38,7\%) from 40 to 59 , and 34 (45.3\%) were 60 years or older. Of the total population, 74 patients were tested for albumin, 64 for vitamin D, and 41 had a nasal swab taken. Table 1 shows the distribution of the patients by gender and age group and the average values of albumin and vitamin $D$, as well as the classification of albumin into normal and hypoalbuminemia categories, of vitamin D into normal, insufficient, and deficient, and of nasal swabs into positive and negative

The average of albumin value was $3.76 \mathrm{~g} / \mathrm{dL}$ among the patients (SD: $0.53 \mathrm{~g} / \mathrm{dL}$ ), ranging from 2.3 to $4.7 \mathrm{~g} / \mathrm{dL}$. Considering values between 3.5 and $5.5 \mathrm{~g} / \mathrm{dL}$ to be normal, $70.3 \%(52 / 74)$ of the individuals had normal results and $29.7 \%$ (22/74) had values below the cutoff. The average vitamin D count was $16.64 \mathrm{ng} / \mathrm{mL}$ (SD: $7.43 \mathrm{ng} / \mathrm{mL}$ ), with values obtained between 4.8 and $31.5 \mathrm{ng} / \mathrm{mL}$. In relation to the classification of the level of vitamin D, we observed that $3.1 \%(2 / 64)$ of the patients had a normal level ( $\geq 30 \mathrm{ng} / \mathrm{mL}), 32.8 \%(21 / 64)$ had a level considered to be insufficient (between 20 and $30 \mathrm{ng} / \mathrm{mL}$ ), and $64.1(41 / 64)$ had deficient levels $(<20 \mathrm{ng} / \mathrm{mL})$. The final parameter analyzed, the results from the nasal swab, showed that $4(9.8 \%)$ patients had positive results, 2 of whom (4.9\%) tested positive for MRSA.

The analysis of the correlation between the exam results and the patient age groups (Table 2) showed that there was a significant difference in the albumin level in relation to age $(p=0.007)$ : the older the age group, the lower the albumin value. The occurrence of hypoalbuminemia in relation to age group was significantly higher in individuals 60 years of age or older $(p<0.001)$. However, no correlation was observed between the values of vitamin $D$ or the results of the nasal swab and age ( $p=0.603$ and 0.725 , respectively). 
Table 1. Description of personal characteristics and the laboratory tests performed.

\begin{tabular}{|c|c|}
\hline Variable & Description n (\%) \\
\hline \multicolumn{2}{|l|}{ Age Group (years) } \\
\hline$<18$ & $7(9.3)$ \\
\hline $18-39$ & $5(6.7)$ \\
\hline $40-59$ & $29(38.7)$ \\
\hline $60+$ & $34(45.3)$ \\
\hline \multicolumn{2}{|l|}{ Gender } \\
\hline Female & $47(62.7)$ \\
\hline Male & $28(37.3)$ \\
\hline \multicolumn{2}{|l|}{ Albumin } \\
\hline Average (SD) & $3.76(0.53)$ \\
\hline Mean (min; max) & $3.85(2.3 ; 4.7)$ \\
\hline \multicolumn{2}{|l|}{ Classification of albumin } \\
\hline$\geq 3,5$ (normal) & $52(70.3)$ \\
\hline$<3,5$ (ow) & $22(29.7)$ \\
\hline \multicolumn{2}{|l|}{ Vitamin D } \\
\hline Average (SD) & $16.64(7.43)$ \\
\hline Mean (min; max) & $15.65(2.8 ; 31.5)$ \\
\hline \multicolumn{2}{|l|}{ Classification of vitamin D } \\
\hline 30 or + (normal) & $2(3.1)$ \\
\hline 20 to 30 (insufficient) & $21(32.8)$ \\
\hline$<20$ (deficient) & $41(64.1)$ \\
\hline \multicolumn{2}{|l|}{ Nasal swab } \\
\hline Positive & $4(9.8)$ \\
\hline Negative & $37(90.2)$ \\
\hline
\end{tabular}

Patients in the study did not take all the tests.

Table 2. Description of laboratory tests evaluated by patient age group and statistical correlation.

\begin{tabular}{|c|c|c|c|c|c|}
\hline \multirow{2}{*}{ Variable } & \multicolumn{4}{|c|}{ Age Group (years) } & \multirow{2}{*}{ p } \\
\hline & $<18$ & $18-39$ & $40-59$ & $60+$ & \\
\hline \multicolumn{6}{|c|}{ Albumin } \\
\hline Average (SD) & $4.15(0.24)$ & $4.02(0.31)$ & $3.88(0.49)$ & $3.54(0.55)$ & \multirow[b]{2}{*}{$0.007^{\star}$} \\
\hline $\begin{array}{c}\text { Mean } \\
\text { (min; max) }\end{array}$ & $4.1(3.9 ; 4.6)$ & $4(3.7 ; 4.5)$ & $3.9(2.8 ; 4.7)$ & $3.4(2.3 ; 4.7)$ & \\
\hline \multicolumn{6}{|c|}{ Classification of albumin, $\mathrm{n}(\%)$} \\
\hline $3.5+($ normal) & $6(100)$ & $5(100)$ & $25(86.2)$ & $16(47.1)$ & \multirow{2}{*}{$\begin{array}{c}< \\
0.001 \\
\end{array}$} \\
\hline$<3.5$ (low) & $0(0)$ & $0(0)$ & $4(13.8)$ & 18 (52.9) & \\
\hline \multicolumn{6}{|c|}{ Vitamin D } \\
\hline Average (SD) & $17.31(6.33)$ & $15.26(6.94)$ & $15.42(7.36)$ & $17.85(7.98)$ & \multirow[b]{2}{*}{$0.666^{\star}$} \\
\hline $\begin{array}{l}\text { Mean (min; } \\
\text { max) }\end{array}$ & 14.9(10.6; 28.5) & $13.7(9 ; 25)$ & $15.4(2.8 ; 28.9)$ & $\begin{array}{c}\text { 19.2(4.7; } \\
31.5)\end{array}$ & \\
\hline \multicolumn{6}{|c|}{ Classification of Vitamin D, $\mathrm{n}(\%)$} \\
\hline $30+($ normal $)$ & $0(0)$ & $0(0)$ & $0(0)$ & $2(7.4)$ & \multirow{3}{*}{0.603} \\
\hline $\begin{array}{c}20 \text { to } 30 \\
\text { (insufficient) }\end{array}$ & $2(28.6)$ & $1(20)$ & $8(32)$ & $10(37)$ & \\
\hline $\begin{array}{c}<20 \\
\text { (deficient) }\end{array}$ & $5(71.4)$ & $4(80)$ & $17(68)$ & $15(55.6)$ & \\
\hline \multicolumn{6}{|c|}{ Nasal swab, n (\%) } \\
\hline Positive & $1(20)$ & $0(0)$ & $2(12.5)$ & $1(5.3)$ & \multirow{2}{*}{0.725} \\
\hline Negative & $4(80)$ & $1(100)$ & $14(87.5)$ & $18(94.7)$ & \\
\hline
\end{tabular}

The analysis of the correlation between the exam results and gender (Table 3) showed no significant difference in any of the parameters. The average albumin values and the occurrence of hypoalbuminemia were statistically similar between the sexes, with $p$ values equal to 0.230 and 0.865 , respectively. There was also a statistical similarity between the sexes in the average values of vitamin $D(p=$ 0.568) and their categorizations as normal, insufficient, and deficient $(p=0.633)$. All four patients with positive nasal swabs were female, but the statistical comparison between the sexes was similar in terms of the positivity of the exam ( $p=0.118)$.

\section{DISCUSSION}

It is mandatory an extensive preoperative evaluation prior to the complex surgery, including complex spinal surgeries. As part of this evaluation, an analysis of the nutritional condition of the patient, which can be determined by the level of serum albumin, 3,4 is critical, as an increased rate of complications has been documented in spine surgery as a result of malnutrition.

The results of this study show that the average level of albumin in the sample was 3.76 (SD: 0.53), higher than the reference value $(3.5 \mathrm{~g} / \mathrm{dL})$, and that most patients $(70.3 \%)$ had normal albumin levels. However, we observed a significant reduction in the average values of albumin on patients of the older age group ( $p=0.007$ ), with a significant increase in the occurrence of hypoalbuminemia. Taking the 60 years of age or older group into account, 18 patients (52.9\%) had hypoalbuminemia, while $16(47.1 \%)$ had normal levels of albumin. These data agree with the observations of Lenke et al., ${ }^{2}$ who noted a worse nutritional state, including an albumin analysis, in more elderly individuals. There was neither any significant correlation between the average albumin values nor between the occurrences of hypoalbuminemia and the gender of the patients.

Another nutrient that plays an important role in mineral homeostasis and bone quality is vitamin $D, 5,6$ recently recognized as a hormone. One article reported an average of $35 \mathrm{ng} / \mathrm{mL}$ of vitamin $D$ and values considered to be normal in $57 \%$ of the individuals who underwent orthopedic surgery. ${ }^{13}$ A recent study reported a prevalence of vitamin $D$ deficiency in a population of patients who had undergone arthrodesis of the spine, with an

Table 3. Description of laboratory tests evaluated by sex of patients and statistical correlation.

\begin{tabular}{l|c|c|c}
\hline \multirow{2}{*}{ Variable } & \multicolumn{2}{|c|}{ Gender } & \multirow{2}{*}{$\mathbf{p}$} \\
\cline { 2 - 3 } & Female & Male & \\
\hline
\end{tabular}

\begin{tabular}{|c|c|c|c|}
\hline \multicolumn{4}{|l|}{ Albumin } \\
\hline Average (SD) & $3.7(0.51)$ & $3.85(0.57)$ & \multirow{2}{*}{$0.230^{* *}$} \\
\hline Mean (min; max) & $3.8(2.3 ; 4.7)$ & $3.95(2.8 ; 4.7)$ & \\
\hline \multicolumn{4}{|c|}{ Classification of Albumin, $n(\%)$} \\
\hline $3.5+$ (normal) & $32(69.6)$ & $20(71.4)$ & \multirow{2}{*}{0.865} \\
\hline$<3.5$ (low) & $14(30.4)$ & $8(28.6)$ & \\
\hline \multicolumn{4}{|l|}{ Vitamin D } \\
\hline Average (SD) & $16.24(7.18)$ & $17.36(7.97)$ & \multirow{2}{*}{$0.568^{\star *}$} \\
\hline Mean (min; max) & $15.6(4.3 ; 30)$ & $18.2(2.8 ; 31.5)$ & \\
\hline
\end{tabular}

Classification of Vitamin D, n (\%)

\begin{tabular}{c|c|c|c}
\hline $30+$ (normal) & $1(2.4)$ & $1(4.3)$ & \multirow{2}{*}{$0.633 \#$} \\
\cline { 1 - 3 } $20-30$ (insufficient) & $12(29.3)$ & $9(39.1)$ & \\
\cline { 1 - 3 }$<20$ (deficient) & $28(68.3)$ & $13(56.5)$ & \\
\hline
\end{tabular}

Nasal swab, n (\%)

\begin{tabular}{c|c|c|c}
\hline Positive & $4(17.4)$ & $0(0)$ & \multirow{2}{*}{$0.118^{*}$} \\
\cline { 1 - 3 } Negative & $19(82.6)$ & $18(100)$ & \\
\hline
\end{tabular}

Chi-squared test; *Fisher exact test; \#Likelihood ratio test; ** Student's t-test 
average value of $29.1 \mathrm{ng} / \mathrm{mL}$ (SD: 14.1), an insufficiency rate of $57 \%$, and a deficiency rate of $27 \% .{ }^{14}$ In the results from our study, we observed that the occurrence of hypovitaminosis $D$ was even higher, with an insufficiency rate of $32.8 \%$ and a deficiency rate of $64.1 \%$, and only $3.1 \%$ of the patients with a normal rate of vitamin $\mathrm{D}$, as well as a much lower average value of vitamin $\mathrm{D}$ at $16.64 \mathrm{ng} / \mathrm{mL}$ (SD: $7.43 \mathrm{ng} / \mathrm{mL}$ ).

Despite the significant reduction in the metabolism of vitamin $D$ in the skin of elderly individuals, ${ }^{5}$ neither study identified an inverse correlation between age and amount of vitamin D.,13 In the study by Stoker and collaborators, ${ }^{6}$ the patients with vitamin D deficiency were significantly younger than those who were not deficient in vitamin $D(p<0.01)$, most of them younger than 50 years of age. In our study, there was no significant correlation between the average value of vitamin $D$ and the age group ( $p=0.666)$ or between the occurrence of insufficiency or deficiency and age group ( $p$ $=0.603$ ). There was no significant correlation between either average vitamin $D$ values or the occurrence of hypovitaminosis $D$ and the gender of the patients.

Subjects who live in regions at higher latitudes, more distant from the equator, are less predisposed to ultraviolet radiation exposure, which is responsible for the metabolism of vitamin D in the skin, and they tend to have lower serum levels of vitamin D. However, while the study by Stoker and collaborators involved patients from the region around Saint Louis, MO, in the United States, at a latitude of $38^{\circ} \mathrm{N}$, the patients in this study were from the environs of São Paulo, SP, at a latitude of $23^{\circ} \mathrm{S}$ and had lower values of vitamin D. However, while the study by Stoker and collaborators involved patients from the region around Saint Louis, $\mathrm{MO}$, in the United States, at a latitude of $38^{\circ} \mathrm{N}$, the patients in this study were from the environs of São Paulo, SP, at a latitude of $23^{\circ}$ $S$ and had lower amounts of vitamin D. A possible cause could be the use of dietary supplements, more common in countries like the USA than in Brazil.

The last parameter analyzed was the investigation of bacteria through a nasal swab, the positive result of which can carry with it an increased risk of infection in patients admitted to the hospital. ${ }^{8-10}$ One randomized, double-blind study reported that the nasal swab results of 1251 out of 6771 patients (18.4\%) tested positive for $S$. aureus, all of them methicillin-susceptible. The results of this study, despite the much smaller number of nasal swabs collected than that obtained in the study described, show that 4 out of 41 patients $(9.8 \%)$ tested positive for S. aureus. However, in 2 patients $(50 \%$ of the positive cases and $4.9 \%$ of the total sample) with positive nasal swabs, the bacteria isolated (S. aureus) was resistant to oxacillin There was no correlation between the positivity of the nasal swab and the patient age groups ( $p=0.725)$ or with the gender of the individuals $(p=0.118)$.

Although all the parameters analyzed were associated with an increased rate of surgical complications, the objective of this study was to present data about a sample population of Brazilian patients who underwent spinal surgery, information that has not been made available before. No correlation analysis was performed between the albumin level (inferring malnutrition), vitamin D level, and nasal swab results and the postoperative clinical outcomes of the patients included in the study. However, we are collecting data about the patient complications and clinical outcomes, prospectively, to be able to conduct this analysis as soon as possible.

\section{CONCLUSIONS}

This study presents data about the status of albumin, vitamin D, and nasal swabs in a population sample of Brazilian patients who underwent spinal surgery, information that has been unavailable to the date. There was a correlation between hypoalbuminemia, inferring malnutrition, and an increase in the patient age group. Almost all patients had some degree of hypovitaminosis D, but with no correlation with age group.

All authors declare no potential conflict of interest concerning this article.

AUTHOR CONTRIBUTIONS: Each author made significant individual contributions to the development of the manuscript. DBS researched and organized the patient data and wrote the article. RRP conceived the project and helped define and revise it. MMM and CB helped to collect and organize the data. CEB, FPS, and CEO provided the patients considered in the study.

\section{REFERENCES}

1. Einhorn TA, Bonnarens $\mathrm{F}$, Burstein $\mathrm{AH}$. The contributions of dietary protein and mineral to the healing of experimental fractures. A biomechanical study. J Bone Joint Surg Am. 1986;68(9):1389-95.

2. Lenke LG, Bridwell KH, Blanke K, Baldus C. Prospective analysis of nutritiona status normalization after spinal reconstructive surgery. Spine (Phila Pa 1976) 1995;20(12):1359-67.

3. Jensen JE, Jensen TG, Smith TK, Johnston DA, Dudrick SJ. Nutrition in orthopaedic surgery. J Bone Joint Surg Am. 1982:64(9):1263-72.

4. Franch-Arcas G. The meaning of hypoalbuminaemia in clinical practice. Clin Nutr. 2001;20(3):265-9.

5. Holick MF. Vitamin D deficiency. N Engl J Med. 2007:357(3):266-81.

6. Stoker GE, Buchowski JM, Bridwell KH, Lenke LG, Riew KD, Zebala LP. Preoperative vitamin D status of adults undergoing surgical spinal fusion. Spine (Phila Pa 1976). 2013;38(6):507-15

7. Ponnusamy KE, Iyer S, Gupta G, Khanna AJ. Instrumentation of the osteoporotic spine: biomechanical and clinical considerations. Spine J 2011;11:54-63.

8. Luzar MA, Coles GA, Faller B, Slingeneyer A, Dah GD, Briat C, et al. Staphylococcus au- reus nasal carriage and infection in patients on continuous ambulatory peritoneal dialysis. N Engl J Med. 1990;322(8):505-9

9. Kluytmans JA, Mouton JW, ljzerman EP, Vandenbroucke-Grauls CM, Maat AW, Wagenvoort JH, et al. Nasal carriage of Staphylococcus aureus as a major risk factor for wound infections after cardiac surgery. J Infect Dis. 1995:171(1):216-9.

10. Nouwen J, Schouten J, Schneebergen P, Snijders S, Maaskant J, Koolen M, et al. Staphylococcus aureus carriage patterns and the risk of infections associated with continuous peritoneal dialysis. J Clin Microbiol. 2006:44(6):2233-6.

11. Bertrand X, Slekovec $C$, Talon D. Use of mupirocin-chlorhexidine treatment to prevent Staphylococcus aureus surgical-site infections. Future Microbiol. 2010;5(5):701-3.

12. Rosen CJ. Clinical practice. Vitamin D insufficiency. N Engl J Med. 2011:364(3):248-54

13. Bogunovic L, Kim AD, Beamer BS, Nguyen J, Lane JM. Hypovitaminosis D in patients scheduled to undergo orthopaedic surgery: a single-center analysis. J Bone Joint Surg Am. 2010;92(13):2300-4.

14. 15. Klein JD, Hey LA, Yu CS, Klein BB, Coufal FJ, Young EP, et al. Perioperative nutrition and postoperative complications in patients undergoing spinal surgery. Spine (Phila Pa 1976). 1996;21(22):2676-82 